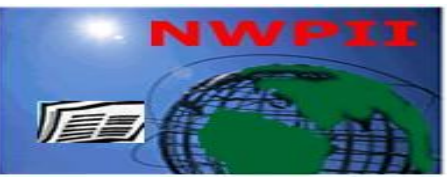

American Journal of Biomedical Sciences

ISSN: 1937-9080

nwpii.com/ajbms

\title{
Effects of Isotretinoin on the Reproduction of Pubertal Male Mice and Malformations in the Offspring
}

\author{
A C C Bispo, T C GALVÃo, V M Tamoyese, G A Costa, S P Ramos, M J S Salles*
}

Laboratório de Toxicologia do Desenvolvimento, Departamento de Biologia Geral, Centro de Ciências Biológicas, Universidade Estadual de Londrina, Londrina/PR.

"Corresponding Author

M J S Salles

Departamento de Biologia Geral

Centro de Ciências Biológicas

Universidade Estadual de Londrina

Londrina/PR - CCB.Campus Universitário

Rodovia Celso Garcia Cid/Pr 445 Km 380

Caixa Postal: 10.011 - CEP: 86057-970 - Londrina, Paraná,

Brasil.

Email: salmjs00@gmail.com

Received: 01 November 2017; | Revised: 08 December 2017; | Accepted: 20 December 2017

\begin{abstract}
Isotretinoin is a vitamin A derivative, taken orally for the treatment of several dermatoses, including severe acne. This condition affects, principally, $80 \%$ of adolescents, males being the most affected. The objective of this study was to analyze the effects of isotretinoin on the reproductive system of pubertal males, and the possible teratogenic effect on the offspring. $1 \mathrm{mg} / \mathrm{kg} / \mathrm{day}$ of isotretinoin was administered to pubertal male Swiss mice for 45 days, via gavage. On the 35 th day the animals were placed to mate with females, after which they continued to be treated for another 10 days, and on the 46th day the male mice were euthanized. Vital and sexual organs of the males were analyzed for toxicity assessment and determination of reproductive function. On the 18th day of pregnancy the females were euthanized for evaluation of intrauterine development and the presence of congenital malformations in the offspring. The results demonstrated that the administration of isotretinoin did not promote toxicity in males, but decreased the weight of the reproductive organs, and decreased testosterone levels and the Johnsen score, including a decrease in Sertoli and Leydig cell numbers. Isotretinoin promoted alterations in the spermatic morphology of both head and tail, however, did not alter the fertility rate. Regarding the intrauterine development of the offspring, there was no impairment of fetal growth; however, the drug led to decreased fetal viability, increased resorption rate, and post implantation loss, added to which skeletal and visceral malformations were identified. It is concluded that isotretinoin presented a potential toxic effect on the male reproductive system by inducing spermatic alterations which had repercussions in offspring malformations.
\end{abstract}

Keywords: spermatogenesis; isotretinoin; offspring; reproduction 


\section{Introduction}

Acne is a genetic-hormonal inflammatory disease of the pilosebaceous follicles, which usually appears at puberty and persists in adulthood ${ }^{[1]}$. The overall prevalence of acne in adolescents is $80 \%$ [2]. Adrenal maturation and gonadal development lead to androgen production, and subsequent sebaceous gland enlargement, culminating in the eruption of acne at puberty. Male adolescents are the most affected ${ }^{[3,4]}$.

13-cis-retinoic acid (isotretinoin, 13-cis-RA) is a compound derived from vitamin $\mathrm{A}$, used to treat a variety of dermatoses, principally acne ${ }^{[5]}$. Retinoids act in the growth and differentiation of epidermal cells, in addition to interfering in the activity of the sebaceous gland, possessing immunomodulatory and anti-inflammatory properties ${ }^{[6]}$.

According to Ellis, $2001^{[7]}$, the adverse effects of this drug are hepatic dysfunction, altered metabolism, e.g., mucocutaneous effects ${ }^{[6]}$, and neuropsychiatric symptoms ${ }^{[8]}$. It becomes highly teratogenic when administered in the first trimester of pregnancy ${ }^{[1,9]}$.

Studies examining the effects of isotretinoin on male reproductive performance and offspring development are scarce. Considering the widespread use of this drug by men during adolescence, the aims of this work was to evaluate the effects of isotretinoin on the reproduction of the pubertal male mice, and the possible effects on offspring.

\section{Materials and Methods}

All procedures described in this study are in accordance with the Ethical Principles of Animal Experimentation of the Federal Council of Veterinary Medicine and Law no. 9605 (regulated by Decree 3179, December 21, 1999)] and were approved by the Ethics Committee on Animal Experimentation of the State University of Londrina, no. 2919201779/2017.

\subsection{Isotretinoin}

Isotretinoin is used in tablet form, commercially known as Roacutan. In the treated group $1 \mathrm{mg} / \mathrm{kg} /$ day of isotretinoin was administered by gavage, and the control group received the equivalent volume of vegetable oil excipient in the same experimental design.

\subsection{Animals}

Swiss mice (Mus musculus) were used in the study; 30 pubertal males and 60 mature, nulliparous females. The animals were 35 days old, weighed approximately 25 grams, originating from the central laboratory of the Biological Sciences Center of the State University of Londrina. During the execution of this study, the animals were maintained in a controlled lighting system, light/dark cycle of 12 hours, at $22 \pm 2{ }^{\circ} \mathrm{C}$, with access to water and feed ad libitum.

\subsection{Experimental Design}

The experimental design is summarized in figure I. The administration period was based on the spermatogenic cycle of mice, corresponding to 35 days ${ }^{[10]}$. On the 35 th day the males were placed to mate with females that had not undergone any treatment, at the ratio of one male to two females. The male animals continued to be treated for a further 10 days, corresponding to two estrus cycles in the females.

On the following days, at 12 hour intervals, the female vaginas were examined to verify the occurrence of a "vaginal plug" that determined day zero of gestation, at which time the females were identified and weighed.

\subsection{Analysis of the males}

On the 46th day, the males were euthanized by cervical dislocation. Blood from the animals was collected and a laparotomy performed to remove organs such as the heart, lungs, liver, kidneys, testes, epididymis, and seminal vesicles. The organs were weighed and analyzed externally. The collected blood was submitted to testosterone dosage, using the radioimmunoassay method. During the treatment period, body mass was monitored and observation was carried out for the presence of piloerection; diarrhea; motor skills; and the occurrence of death, all clinical signs indicative of toxicity. 


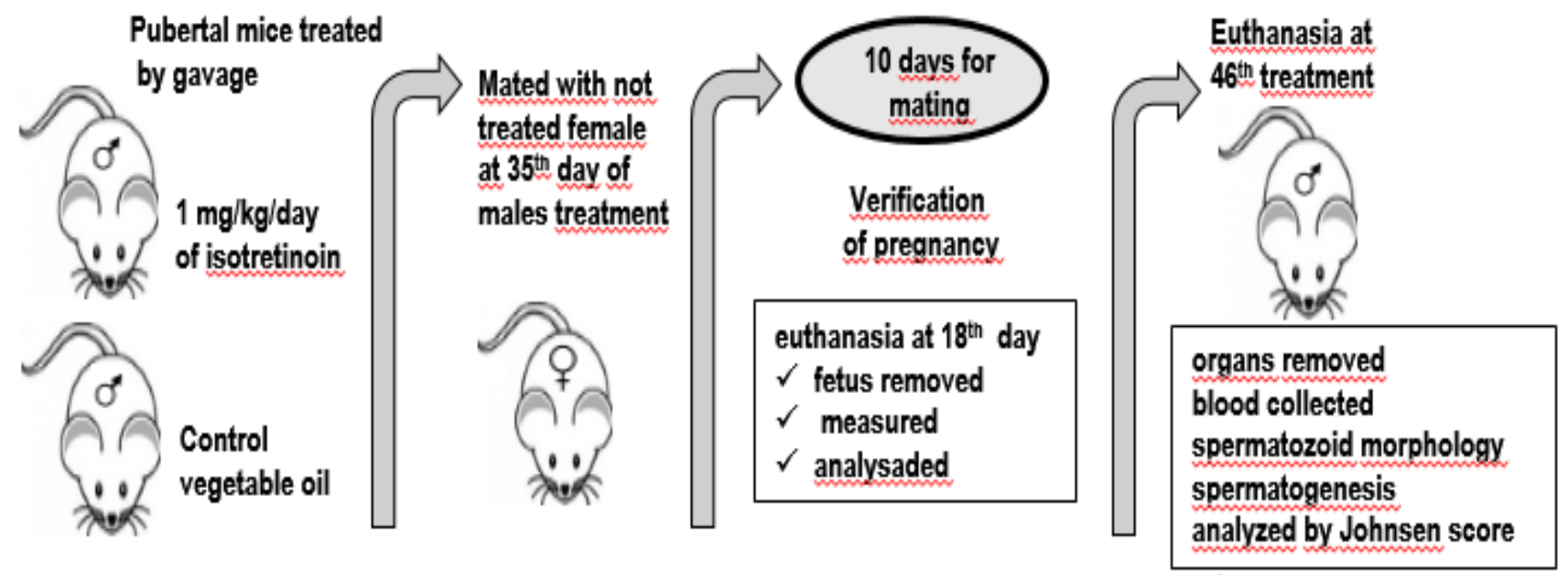

Figure I The general scheme of experimental design

For evaluation of spermatic morphology, the methodology described by Wyrobek, $1983^{[11]}$ was used. Spermatozoa were collected from the tail of the epididymis and 400 cells per animal were evaluated under a light microscope at 1000x resolution. The testes were fixed in Bouin's solution and histologically processed using hematoxylineosin dye for observation through microscopy.For the analysis of spermatogenesis the protocol of Johnsen, $1970^{[12]}$ was used. A total of 40 seminiferous tubules were analyzed per animal, and the histological evaluation was classified on a scale of 1 to 10 , according to the presentation of the tubules. The minimum score represents some cells of the germinal line absent and few Sertoli cells in the epithelium of the seminiferous tubule. The maximum score represents the epithelium of the seminiferous tubule with all the cells that make up spermatogenesis, including Sertoli cells, which were also quantified. This analysis was performed with the aid of microscopic light at a resolution of $400 x$. For evaluation of the interstitial tissue, the Leydig cells were counted in 20 different areas, per animal, with the aid of a microscopic light, at a resolution of 400x.

\subsection{Fetal analysis}

On the 18th day of gestation, the females were euthanized by cervical dislocation, and a laparotomy and hysterectomy performed to analyze the uterine contents, verifying the presence of resorptions, number of live and dead fetuses, and placental weight. From these data, the resorption index, post-implantation loss index, fetal viability index, and placental index were calculated.

All live fetuses were weighed, measured, and evaluated externally. The correlation of fetal weight to gestational age was also verified, according to Calderon [13]. For evaluation of congenital malformations, half the fetuses were fixed in Bodian's solution for the visceral analysis, and the other half in acetone for the skeletal analysis ${ }^{[14]}$. The visceral analysis was performed through the cuts/microdissection proposed by Barrow and Taylor ${ }^{[15]}$ and to study the thorax, abdomen, and head the strategic cuts proposed by Wilson ${ }^{[16]}$ were used. The fetuses submitted to skeletal analysis were evaluated for the detection of abnormalities of the skull, sternum, vertebrae, ribs, pelvis, clavicle, phalanges, metacarpal, and metatarsal, according to the Taylor method ${ }^{[17]}$. These evaluations were carried out under a stereoscopic microscope. 


\subsection{Statistical Analyzes}

After verifying the normality of the samples with the Shapiro Wilk test, the $\mathrm{T}$ test associated with one-way ANOVA were used for the quantitative analyzes, such as organ weight, testosterone dosage, histological analysis of the testes, and uterine contents. For the qualitative analyzes, such as morphology of spermatozoa, the Chi-Squared test was used and Fisher's test for analyzes of skeletal and visceral malformations. The statistical program used was GraphPad Prism and the level of significance adopted was 5\%.

\section{Results}

\subsection{Analysis of the Males}

There were no significant alterations in the organs lung, heart, kidneys, and liver as shown in table I. In addition, there were no clinical signs of toxicity such as piloerection, redness of eyes, decrease in body mass, diarrhea, lack of motor coordination, or death in the males.

With regard to the reproductive organs, we observed a decrease in epididymal, vesicle, and testis weights significant compared to the control group. The testosterone dosage was also lower in the treated group, according to the data shown in table I

Table I Parameters related to toxicity of the male mice.

\begin{tabular}{ccc}
\hline Parameters & $\mathbf{G}_{\mathbf{0}}$ & $\mathbf{G}_{\mathbf{1}}$ \\
\hline Number of males & $\mathbf{1 5}$ & $\mathbf{1 5}$ \\
\hline Weight gain (g) & $-0.554 \pm 0.669$ & $-0.650 \pm 0.749$ \\
Lung (g) & $0.228 \pm 0.015$ & $0.239 \pm 0.012$ \\
Kidneys (g) & $0.513 \pm 0.017$ & $0.505 \pm 0.013$ \\
Liver (g) & $1.887 \pm 0.065$ & $1.882 \pm 0.061$ \\
Heart (g) & $0.166 \pm 0.006$ & $0.161 \pm 0.005$
\end{tabular}

Data presented as average and error. Tests used T Test/ANOVA. $\mathrm{G}_{0}$ corresponds to the control group and $\mathrm{G}_{1}$ to the treated group.

Table II Evaluation of reproductive organs and testosterone dosage.

\begin{tabular}{ccc}
\hline Parameters & $\mathbf{G}_{\mathbf{0}}$ & $\mathbf{G}_{\mathbf{1}}$ \\
\hline Number of males & $\mathbf{1 5}$ & $\mathbf{1 5}$ \\
\hline Epididymis (g) & $0.105 \pm 0.002$ & $0.080 \pm 0.002^{*}$ \\
Filled vesicles (g) & $0.222 \pm 0.015$ & $0.176 \pm 0.013^{* *}$ \\
Empty vesicles (g) & $0.147 \pm 0.012$ & $0.105 \pm 0.009^{* *}$ \\
Testes (g) & $0.221 \pm 0.009$ & $0.199 \pm 0.010^{*}$ \\
Testosterone (ng/ml) & $242.3 \pm 0.592$ & $216.2 \pm 0.464 * *$
\end{tabular}

Data presented as average and error. Tests used T Test/ANOVA. $\mathrm{G}_{0}$ corresponds to the control group and $\mathrm{G}_{1}$ to the treated group. Significance $* \mathrm{p}<0.5 * * \mathrm{p}<0.01$ and $* * * \mathrm{p}<0.001$. 
Table III Histological analysis of the testes.

\begin{tabular}{ccc}
\hline Parameters & $\mathbf{G}_{\mathbf{0}}$ & $\mathbf{G}_{\mathbf{1}}$ \\
\hline Number of tubules analyzed & $\mathbf{4 0}$ & $\mathbf{4 0}$ \\
per animal & & \\
\hline Johnsen Score & $9.28 \pm 0.108$ & $8.47 \pm .132^{* * *}$ \\
Sertoli cells & $8.57 \pm 0.572$ & $8.00 \pm 0.348^{*}$ \\
Leydig cells & $4.41 \pm 0.149$ & $2.58 \pm 0.193^{* * *}$
\end{tabular}

Data presented as average and error. Tests used T Test/ANOVA. $\mathrm{G}_{0}$ corresponds to the control group and $\mathrm{G}_{1}$ to the treated group. Significance $* \mathrm{p}<0.5$ and $* * * p<0.001$.

Table III shows the results of the Johnsen analysis performed on the testes. In the morphological evaluation of the spermatozoa, there were head and tail abnormalities in the treated groups. The principal morphological alterations of the sperm heads were bifurcations, absence, and irregular shape. The tail alterations were extensions, shortenings, and bifurcations. Data shown in table IV.

The analysis of reproductive performance in both groups presented a fertility rate of $90 \%$, according to the data shown in table $\mathrm{V}$

Table IV:Morphological evaluation of the spermatozoa contained in the epididymis.

\begin{tabular}{ccc}
\hline Parameters & $\mathbf{G}_{\mathbf{0}}$ & $\mathbf{G}_{\mathbf{1}}$ \\
\hline Number of spermatozoa analyzed per animal & $\mathbf{4 0 0}$ & $\mathbf{4 0 0}$ \\
\hline Spermatozoa with alteration in tail & $16.80 \%$ & $22.57 \%^{*}$ \\
Spermatozoa with alteration in head & $1.70 \%$ & $6.60 \% *$
\end{tabular}

Data presented in \% of malformations of spermatozoa in each group. Test used Chi-Squared test. $\mathrm{G}_{0}$ corresponds to the control group and $\mathrm{G}_{1}$ to the treated group. Significance $* \mathrm{p}<0.5$.

Table V:Analysis of reproductive performance.

\begin{tabular}{ccc}
\hline Parameters & $\mathbf{G}_{\mathbf{0}}$ & $\mathbf{G}_{\mathbf{1}}$ \\
\hline Fertile males/number of & $15 / 15$ & $15 / 15$ \\
mated males & & $27 / 30$ \\
Pregnant females/number of & $27 / 30$ & \\
mated females & & 90
\end{tabular}

Data expressed as absolute values and \%. Tests used T Test/ANOVA. $\mathrm{G}_{0}$ corresponds to the control group and $\mathrm{G}_{1}$ to the treated group. 


\subsection{Analysis of fetuses}

The uterine contents of the females were analyzed in order to verify intrauterine development. The parameters of the treated group which presented statistically significant alterations were the presence of a lower number of live fetuses, resorptions, resorption rate, post implantation losses, and fetal viability, when compared to the control animals. The results corresponding to the numbers of implantations, placental index, uterine weight, and placental weights were not statistically significant, according to the data presented in table VI.

Table VI:Analysis of the parameters of intrauterine development.

\begin{tabular}{ccc}
\hline Parameters & $\mathbf{G}_{\mathbf{0}}$ & $\mathbf{G}_{\mathbf{1}}$ \\
\hline Number of females analyzed & $\mathbf{2 7}$ & $\mathbf{2 7}$ \\
\hline Number of implantations & $12.440 \pm 0.699$ & $12.220 \pm 0.865$ \\
Number of live fetuses & $10.220 \pm 0.641$ & $8.296 \pm 0.736 *$ \\
Number of resorptions & $2.481 \pm 0.438$ & $3.852 \pm 0.626 *$ \\
Resorption rate (\%) & $21.020 \pm 3.392$ & $29.330 \pm 4.417^{* *}$ \\
Post Implantation Losses (\%) & $21.510 \pm 3.347$ & $29.540 \pm 4.414 * *$ \\
Fetal viability (\%) & $78.490 \pm 3.347$ & $70.460 \pm 4.414 * *$ \\
Placental Index & $0.082 \pm 0.002$ & $0.077 \pm 0.004$ \\
Weight of uterus (g) & $17.080 \pm 0.950$ & $16.840 \pm 1.130$ \\
Individual placental weight $(\mathrm{g})$ & $0.106 \pm 0.030$ & $0.098 \pm 0.005$
\end{tabular}

Data presented as average and error. Tests used T Test/ANOVA. G0 corresponds to the control group and G1 to the treated group. Significance $* \mathrm{p}<0.5$ and $* * \mathrm{p}<0.01$.

There were no statistically significant decreases in fetal weight or length, according to the data shown in Table VII.

Table VII:Fetal weight and length.

\begin{tabular}{ccc}
\hline Parameters & $\mathbf{G}_{\mathbf{0}}$ & $\mathbf{G}_{\mathbf{1}}$ \\
\hline Number of fetuses analyzed & $\mathbf{2 7 6}$ & $\mathbf{2 7 4}$ \\
\hline Fetal weight $(\mathrm{g})$ & $1.307 \pm 0.028$ & $1.318 \pm 0.024$ \\
Fetal length $(\mathrm{cm})$ & $2.760 \pm 0.021$ & $2.724 \pm 0.032$
\end{tabular}

Data presented as average and error. Tests used T Test/ANOVA. G0 corresponds to the control group and G1 to the treated group. Significance $* \mathrm{p}<0.5$ and $* * \mathrm{p}<0.01$.

The correlation analysis of fetal weight for gestational age showed that all fetuses presented adequate weight for gestational age (Figure II). 


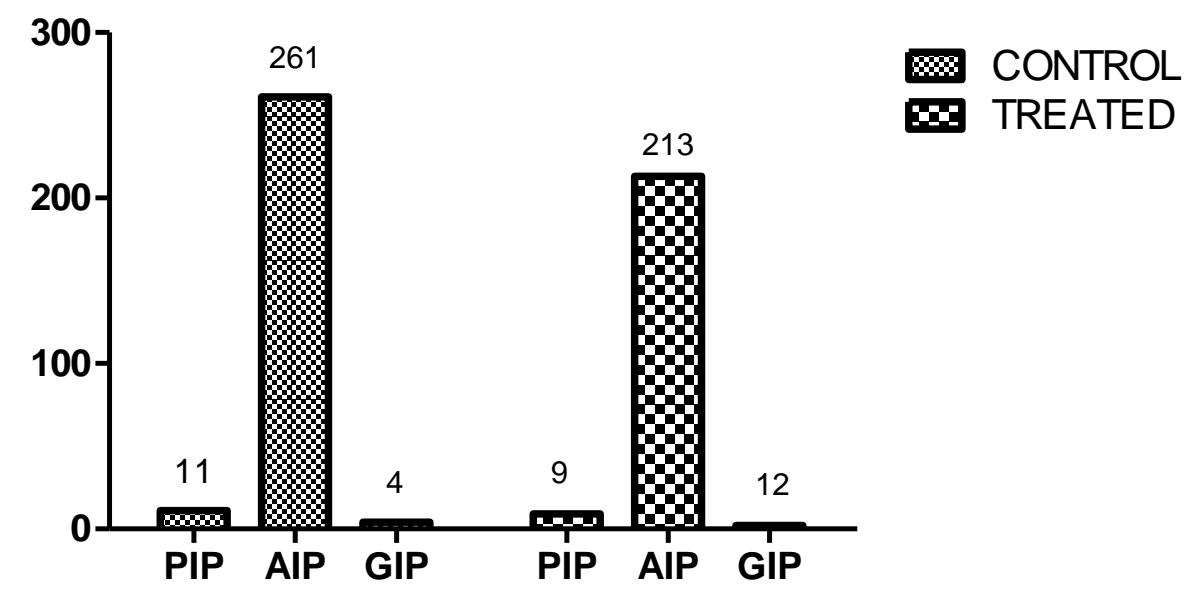

Figure II Adequacy of fetal weight with gestational age of offspring.

Data presented in absolute values. Test used - Fischer test. $\mathrm{G}_{0}$ corresponds to the control group and $\mathrm{G}_{1}$ to the treated group (PIP: low weight for the age of pregnancy; AIP: adequate weight for the age of pregnancy; GIP: high weight for the age of pregnancy).

Skeletal malformations that presented significant alterations were irregularity of the sternum and supraoccipital bones, the absence of supraoccipital bones presented division in the middle, and the sternums with irregular formats. The total number of fetuses analyzed was 139 for palates, and basisphenoids. The majority of the treated group and 143 for the control group. Data shown in table VIII.

Table VIII:Analysis of skeletal malformations of offspring.

\begin{tabular}{ccccc}
\hline Parameters & Frequency & $\mathbf{\% ~ G}_{\mathbf{0}}$ & Frequency & $\mathbf{\% ~ G}_{\mathbf{1}}$ \\
\hline $\begin{array}{c}\text { Number of } \\
\text { fetuses }\end{array}$ & 143 & & 139 & \\
analyzed & & & & \\
\hline Sphenoid & 0 & 0 & 6 & $4.31^{*}$ \\
Hyoid Body & 0 & 0 & 2 & 1.43 \\
Sternum & 13 & 9.09 & 36 & $26.90^{* * *}$ \\
Interparietal & 1 & 0.70 & 4 & 2.87 \\
Carpal bone & 2 & 1.40 & 4 & 2.87 \\
Tarsus bone & 2 & 1.40 & 4 & 2.87 \\
Palate & 1 & 0.70 & 14 & $10.07 * *$ \\
Supraoccipital & 14 & 9.79 & 44 & $31.65^{* * *}$
\end{tabular}

Data presented in absolute and percentage values. Test used - Fischer test. $\mathrm{G}_{0}$ corresponds to the control group and $\mathrm{G}_{1}$ to the treated group. Significance $* \mathrm{p}<0.5 ; * * \mathrm{p}<0.01$ and $* * * \mathrm{p}<0.001$. 
The total number of fetuses analyzed was 133 for the control group and 135 for the treated group. The data of the visceral analysis that presented statistically significant alterations were the olfactory bulbs, heart, lungs, kidneys, and nasal septum. Data shown in table IX.

Table IX:Analysis of visceral malformations of offspring.

\begin{tabular}{|c|c|c|c|c|}
\hline Parameters & Frequency & $\% \mathbf{G}_{0}$ & Frequency & $\% \mathrm{G}_{1}$ \\
\hline $\begin{array}{l}\text { Number of } \\
\text { fetuses } \\
\text { analyzed }\end{array}$ & 133 & & 135 & \\
\hline $3^{\text {rd }}$ Ventricle & 0 & 0 & 3 & 2.22 \\
\hline $4^{\text {th }}$ Ventricle & 4 & 3.01 & 8 & 5.93 \\
\hline Bladder & 1 & 0.75 & 5 & 3.70 \\
\hline Olfactory Bulb & 0 & 0 & 7 & $5.18^{*}$ \\
\hline Heart & 4 & 3.01 & 16 & $11.85^{* *}$ \\
\hline Testicular & 2 & 1.50 & 2 & 1.48 \\
\hline \multicolumn{5}{|l|}{ Ectopia } \\
\hline Lungs & 3 & 2.26 & 11 & $8,15^{*}$ \\
\hline Kidneys & 2 & 1.50 & 7 & $5.18^{*}$ \\
\hline Nasal septum & 2 & 1.50 & 12 & $8.88 * *$ \\
\hline
\end{tabular}

Data presented in absolute and percentage values. Test used - Fischer test. $\mathrm{G}_{0}$ corresponds to the control group and $\mathrm{G}_{1}$ to the treated group. Significance $* p<0.5$; and $* * p<0.01$.

\section{Discussion}

Testing medicines to determine the possible harmful health effects and exposure levels that can be considered safe is of utmost importance. The majority of adverse effects involving the use of retinoids, including isotretinoin, are related to the skin and mucous membranes, nervous system, skeletal muscle, hematopoietic, lymphatic, gastrointestinal, cardiorespiratory, genitourinary ${ }^{[18]}$ and effects on reproduction ${ }^{[19]}$.

The data obtained in the present study showed that the use of $1 \mathrm{mg} / \mathrm{kg} /$ day of isotretinoin did not promote alterations in animal weight gain during treatment, there were also no alterations in vital organs and no clinical signs of toxicity. However, there was a significant decrease in the reproductive organs and in the level of testosterone.

In the histological evaluation of the testicles, the Johnsen score demonstrated that the treated group presented alterations in cells during the spermatogenesis process when compared to the control group. The factors that influenced the score were decreases in the numbers of Leydig cells, Sertoli cells, and cells of the germinal line of the seminiferous tubules analyzed.

Sertoli cells play a key role in the regulation of spermatogenesis and mediate the action of testosterone and follicle-stimulating hormone in the testes ${ }^{[20]}$. In addition, they exhibit functions of support and nutrition of germinal cells, absorb the cytoplasmic remains of the spermatids during spermiogenesis, and transport the immature spermatozoa towards the tubular lumen ${ }^{[21]}$. According to MENDIS-HANDAGAMA and SIRIL ARIVARATNE, $2005^{[22]}$, the Leydig cells differentiate during the pre-pubertal period and have as precursors the mesenchymal cells of the peritubular region. FAWVETT et al., 1973 [23] suggest that the quantity of Leydig cells and disposition of lymphatic vessels in mammals are related to appropriate concentrations of androgens in the testes and in the blood vessels. Testosterone plays a key role in puberty, stimulating the growth, 
development, and secretory activity of vesicular glands, in addition to prolonging the life span of spermatozoa in the epididymis ${ }^{[24,25]}$. Testosterone is involved in the developmental process of puberty, spermatogenesis, and development of secondary sexual characteristics ${ }^{[26]}$. According to CHAUHAN et al., $2007^{[27]}$, the structure and functionality of the epididymis are dependent on testosterone levels.

According to ZHOU et al., 2008 ${ }^{[28]}$ the combined actions of FSH, testosterone and retinoic acid are essential for normal mammalian spermatogenesis. FSH acts on Sertoli cells and can affect spermatogenic populations. Retinoic acid acts on both Sertoli cells and germinal cells and pushes undifferentiated spermatogonia into the pathway of differentiation and, eventually, into meiotic prophase. Any imbalance in the concentration of retinoic acid may cause alterations in the differentiation of undifferentiated spermatogonia at the beginning of meiosis and, possibly, at the beginning of the cycle of the seminiferous epithelium.

Testosterone also acts on Sertoli cells and is required for the formation of spermatozoa. TRAUTMANN et al., 2008 ${ }^{[29]}$ and LIVERA et al., $2002^{[30]}$, demonstrate that the administration of retinoic acid in germ cells is well regulated and that different germinal cells can respond to retinoic acid in different ways. It's important to mentioned that testosterone biosynthesis is regulated primarily by pulsatile secretion of $\mathrm{LH}^{[31]}$.

According to RAYCHOUDHURY et al., 2000 ${ }^{[32]}$ Sertoli cells and Leydig cells may be susceptible to the action of numerous toxic substances that induce morphological and functional alterations, compromising the development of spermatogenesis. Thus, it is suggested that the administration of isotretinoin induced functional alterations of the testicular and morphological endocrine portion of the epididymis, seminal vesicles, and Leydig and Sertoli cells and, consequently, affected spermatogenesis.

The morphological alterations found in spermatozoa heads were bifurcations, absence, and irregular shape. The tails presented extensions, shortenings, and bifurcations. According to BASTH and OKO, 2000 ${ }^{[33]}$, spermatic defects can be influenced by functional variations compromising sperm morphology, from the onset of spermatogenesis in the seminiferous tubules as well as during the period of maturation and storage of spermatozoa in the epididymis. The results obtained for the percentages of sperm abnormalities enables establishment of a correlation with the alterations in the seminiferous epithelium and the reduction in the epididymides.

Although the morphological alterations of the spermatozoa compromise the motility and, consequently, fertilization, in this research the morphological alterations did not affect the fertility rate. However, the alterations influenced the survival of the offspring, reducing the number of live fetuses which had repercussions on the reduction of fetal viability and placental index; increased resorption, and post-implantation loss, leading to a greater number of abortions. One of the most common causes for spontaneous abortion is morphological alterations in the heads of spermatozoa. These alterations are associated with chromosome aneuploidies, that is, the genetic information necessary for the offspring is compromised. Some aneuploid embryos implant and evolve with chromosomal abnormalities, while others are aborted ${ }^{[34]}$.

The fetuses did not present altered length or weight when compared to the control group. The correlation between fetal weight and gestational age was adequate. These data demonstrate that the drug did not alter fetal growth. With regard to the skeletal malformations identified in the offspring of the isotretinoin group, the bones were the sphenoid, sternum, supraoccipital and palate, while the principal visceral malformations observed in this group were dilations in the heart, lungs, kidneys, nasal septum, and olfactory bulb. Considering that the females were not exposed to any teratogenic agent, the occurrence of congenital malformations can be attributed to paternal exposure to the drug. EVGENI et al., 2014 ${ }^{[35]}$, showed that alterations in the heads of spermatozoa cause congenital abnormalities in the offspring of these individuals due to modifications in paternal genetic material ${ }^{[36]}$. According to the findings of the present study it is believed that isotretinoin has genotoxic potential in spermatozoa, promoting an increase in the abortion rate and skeletal and visceral malformations observed in the offspring. 


\section{Conclusion}

The data obtained in the present study demonstrate that paternal exposure to isotretinoin exerted a toxic effect on the reproductive organs, altered the spermatogenesis, affecting the endocrine portion of the testes, and was teratogenic to the offspring. The decrease in numbers of Sertoli and Leydig cells and decreased testosterone production that culminated in alterations in the structure of spermatozoa demonstrate a degenerative testicular process. Structural alterations in the spermatozoa were associated with congenital malformations observed in the offspring. This drug at the dose and design proposed by the present study can be considered harmful to health, serving as an alert for greater attention and follow-up of adolescent men who are treated with isotretinoin.

\section{References}

1 Zouboulis CC, Eady A, Philpott M, Goldsmith LA, Orfanos C, Cunliffe WC, Rosenfield R. What is the pathogenesis of acne? Exp Dermatol 2005; 14(2): 143-152 [PMID: $15679586 \quad$ DOI: $\quad \underline{10.1111 / \mathrm{j} .0906-}$ 6705.2005.0285a.x]

2 Barbieri JS, Hoffstad O, Margolis DJ. Duration of oral tetracycline-class antibiotic therapy and use of topical retinoids for the treatment of acne among general practitioners (GP): A retrospective cohort study. $\boldsymbol{J}$ Am Acad Dermatol 2016; 75(6): 1142-1150 e1141 [PMID: 27502311 DOI: 10.1016/j.jaad.2016.06.057]

3 Hassum, K.M. Acne: Etiopatogenia. Anais Brasileiros de Dermatologia, 2000, 75, 7-15.

4 Costa, A.; Alchrone, M.M.A; Goldschmidt, M.C.B. Fatores etiopatogênicos da acne vulgar. Anais Brasileiros de Dermatologia, 2008, 83, 451-459. DOI: $\quad$ 10.1590/S036505962008000500010 .

5 Diniz , D.G.A.; LimaEM.; Filho N.R.A. Isotretinoína: Perfis farmacológico, farmacocin ético e analítico. Revista Brasileira de Ciê ncias Farmac êuticas, 2002, 38(4), 415-429. DOI: 10.1590/S1516-93322002000400004.

6 Sabroe, R.A.; Staughton, R.C.; Bunker, C.B. Bronchospasm induced by isotretinoin. British Medical Journal, 1996, 312(7035), 886. DOI: 10.1136/bmj.312.7035.886.

7 Ellis CN, Krach KJ. Uses and complications of isotretinoin therapy. $\boldsymbol{J}$ Am Acad Dermatol 2001; 45(5): S150-157 [PMID: 11606947 DOI: 10.1067/mjd.2001.113717]

8 Hull, P.R.; Darcy, C. Isotretinoin use and subsequent depression and suicide: Presenting the evidence. American Journal of Clinical Dermatology, 2003, 4(7), 493-505. DOI: 10.2165/00128071-200304070-00005

9 MAGALHÃES , S.M.S.; Carvalho, W.S. Reações adversas a medicamentos. In: GOMES, M.J.V.; REIS, A.M.N. Ci ê ncias

Farmacêuticas: Uma abordagem em farmácia hospitalar. São Paulo. Atheneu, 2000, 125.

10 Adler, I.D. Spermatogenesis and mutagenicity of environmental hazards: Extrapolation of genetic risk from mouse to man. Andrologia, 2000, 32, 233-237. DOI: 10.1046/j.14390272.2000.00390.x.

11 Wyrobec, A.J.; Gordon, L.A.; Burkhart, J.G.; Francis, M.W.; Kapp JR, R.W.; Letz, G.; Malling, H.V.; et al. An evaluation of the mouse sperm morphology test and other sperm tests in non-human mammals: A report of the US EPA Gene-Tox-Program. Mutation Research, 1983, 115, 1-72. DOI: 10.1016/0165-1110(83)90014-3.

12 Johsen, S.G. Testicular biopsy score count method for registration of spermatogenesis in human testes: Normal values and results in 335 hypogonadal mals. Hormones, 1970, 303, 2-25. DOI: $\underline{10.1159 / 000178170 .}$

13 Calderon, I.M.P.; Rudge, M.V.C.; Brasil, M.A.M. Modelo experimental em ratas para estudo do binômio diabete e gravidez. Acta Cir úrgica Brasileira, 1992, 4, 6-144.

14 Staples , R.E.; Schnel, V.L. Refinements in rapid clearing technic in the $\mathrm{KOH}$-alizarin red $\mathrm{S}$ method for fetal bone. Stain Technology, 1964, 39, 61-63. 
15 Barrow MV, Taylor WJ. A rapid method for detecting malformations in rat fetuses. $\boldsymbol{J}$ Morphol 1969; 127(3): 291-305 [PMID: 4388962 DOI: $10.1002 /$ jmor.1051270303]

16 Wilson, J.G. Methods for administering agents and detecting malformations in experimental animals. Teratology: Principles and Techniques, 1965, 262-277. DOI: 10.1002/jps.2600540944.

17 Taylor, P. Skeletal examination. In: Practical Teratology, 1986, New York: Academic Press, 77-100.

18 White, G. M. Acne therapy. Disease-a-month, 1999, 45(8), 301-332.

19 Gencoglan G, Tosun M. Effects of isotretinoin on spermatogenesis of rats. Cutan Ocul Toxicol 2011; 30(1): 55-60 [PMID: 20973756 DOI: $10.3109 / 15569527.2010 .521537]$

20 Sharpe, R.M. Regulation of spermatogenesis the physiology of reproduction, 1994, New

York: Raven Press, $2^{a}$ ed., 1363-1434.

21 Vogt, H.J.; Ewers, R. 13-cis-Retinoic acid and spermatogenesis: Spermatological and impulse cytophotometric studies. Hautarzt, 2002, 38(4), 281-286.

22 Mendis Handagama, S.M.; Siril Arivaratne, H.B. Leydig cells, thyroid hormones and steroidogenesis. Indian Journal of Experimental Biology, 2005, 43, 939-962. DOI: bitstream/123456789/23265/1/IJEB.

23 FAVWETT, D.W.; NEAVES, W.B.; FLORES, M.N. Comparative observations on intertubular lymphatics and the organization of the interstitial tissue of the mammalian testis. Biology of Reproduction, 1973, 9, 500-532. DOI: $10.1093 /$ biolreprod/9.5.500.

24 Santos, M. D.; Torre, C. A. A.; Ruas, J. R. M.; Machado, G. V.; Coast, D. S.; Angulo, L. M. Concentração sérica de testosterona em touros Zebu. Revista Brasileira de Zootecnia, 2000, 3, 738-744.DOI: 10.5216/cab.v11i1.1769.

25 Krishnamurthy, H.; Danilovich, N.; Morales, C.R.; Sairam, M.R. Qualitative and quantitative decline in spermatogenesis of the follicle-stimulating hormone receptor knockout (FORKO) mouse. Biology Reproduction, $2000,62,1146-1159$.
26 Hafez, E. S. E. Hormônios, fatores de crescimento e reprodução. Reprodução animal.São Paulo: Manole, 1995, 6ª ed.,59-94.

27 Chauhan A, Agarwal M, Kushwaha S, Mutreja A. Suppression of fertility in male albino rats following the administration of $50 \%$ ethanolic extract of Aegle marmelos. Contraception 2007; 76(6): 474-481 [PMID: 18061707 DOI: 10.1016/j.contraception.2007.08.002]

28 Zhou Q, Li Y, Nie R, Friel P, Mitchell D, Evanoff RM, Pouchnik D, Banasik B, McCarrey JR, Small C, Griswold MD. Expression of stimulated by retinoic acid gene 8 (Stra8) and maturation of murine gonocytes and spermatogonia induced by retinoic acid in vitro. Biol Reprod 2008; 78(3): 537-545 [PMID: 18032419 PMCID: PMC3208258 DOI: 10.1095/biolreprod.107.064337]

29 Trautmann E, Guerquin MJ, Duquenne C, Lahaye JB, Habert R, Livera G. Retinoic acid prevents germ cell mitotic arrest in mouse fetal testes. Cell Cycle 2008; 7(5): 656-664 [PMID: 18256537 DOI: $10.4161 / c c .7 .5 .5482]$

30 Livera, G.; Rouiller Fabre, V.; Pairault C.; Levacher, C.; Habert, R. Regulation and perturbation of testicular functions by vitamin

A. Reproduction, 2002;124(2), 173-180.DOI: 10.1530/rep.0.1240173

31 Kaream , S.A.N.; Monem, S.A.E.; Monhssab, M.; Khalil, G.I. Relationship between Testosterone Level, Serum Omentin-1 and Insulin Resistance in Obese Men. American Journal of Biomedical Sciences, 2015, 7(3), 134-147. DOI: 10.5099/aj150300134.

32 Raychoudhury, S.S.; Flowers, A.F.; Millette, C.F.; Finlay, M.F. Toxic effects of polychlorinated biphenyls on cultured rat Sertoli cells. Journal of Andrology, 2000, 21(6), 964-973. DOI: 10.1002/j.19394640.2000.tb03428.x

33 Basth, A.D.; OKO, R.J. Abnormal morphology of bovine spermatozoa. Ames: Iowa State University Press, 1989.

34 Van Assche, V.E.; Bonduelle, M.; Tournave, H.; Joris, H.; Verheven, G.; Devroev, P.; Van Steirghen, A.; Liebaers, I. Cytogenetics of infertile men. Human Reproductive, 1996, 11(4), 1-24. 
35 Evgeni , E; Charalabopoilos , K.; Asimakopoulos, B. Human Sperm DNA Fragmentation and its Correlation with Conventional Semen Parameters. Journal of Reproduction \& Infertility, 2014, 15(1), 2-14.

36 Aitken, R.J.; Koppers, A. Apoptosis and DNA damage in human spermatozoa. Asian Journal of Andrology, 2011, 13, 36-42. 